\title{
TYPOVÉ SCHVÁLENIE AUTONÓMNYCH (SAMOJAZDIACICH) VOZIDIEL
}

\section{TYPE APPROVAL OF AUTONOMOUS (SELF-DRIVING) VEHICLES}

\author{
L’ubomír Moravčík ${ }^{1 * *}$
}

\begin{abstract}
Abstrakt
Technológie automatizácie riadenia vozidiel sa neustále vyvíjajú s ciel’om efektívnejšieho využívania vozidla. Právne predpisy pre schval'ovanie vozidle musia umožnit' túto inováciu a zároveň zabezpečit' bezpečnost' cestnej premávky, kybernetickú bezpečnost' a podobne. Autonómne vozidlá nie sú preto len výzvou pre výrobcov vozidiel, ale aj pre samotné schval'ovacie orgány, ktoré schvalujú vozidlá na prevádzku v cestnej premávke. Musí byt' zaručený vnútorný trh, ktorý podporuje nové technológie a zároveň chráni občanov pred novými rizikami, ktoré predstavujú vozidlá bez vodiča. Nové technológie, ktoré sa nepredpokladajú v súčasných právnych predpisoch sa môžu schválit' na základe výnimky udelenej na základe vnútroštátneho ad hoc posúdenia bezpečnosti. Takýmto spôsobom je možné v súčasnosti schválit’ na prevádzku v cestnej premávke autonómne vozidlá úrovne 3 a 4. Práve vozidlá úrovne 3 a 4 sa už testujú a očakáva sa, že budú dostupné.
\end{abstract}

Kl'účové slová typové schválenie, prevádzka vozidiel, autonómne vozidlá, samojazdiace vozidlá, automatizácia, ovládanie vozidla, mobilita, bezpečnost' cestnej premávky

Summary The technologies of vehicle automation are constantly evolving to make vehicles more efficient. The vehicle approval legislation must allow this innovation while ensuring road safety, cyber security etc. Autonomous vehicles are therefore not only a challenge for vehicle manufacturers, but also for the approval authorities themselves, which authorize vehicles for road traffic. An internal market that promotes new technologies and at the same time protects citizens from the new risks posed by selfdriving vehicles must be guaranteed. New technologies not foreseen in the current legislation can be approved on the basis of a derogation granted under a national ad hoc safety assessment. In this way, level 3 and 4 autonomous vehicles can currently be approved for road traffic. Level 3 and 4 vehicles are already being tested and are expected to be available.

Keywords type approval, operation of vehicles, autonomous vehicles, self-driving vehicles, automation, mobility, vehicle control, road safety

\footnotetext{
${ }^{1}$ Ministerstvo dopravy a výstavby Slovenskej republiky, štátny dopravný úrad, Námestie slobody 6, 81005 Bratislava, Slovenská republika, lubomir.moravcik@mindop.sk *korespondenční autor: L'ubomír Moravčík, e-mail: lubomir.moravcik@mindop.sk
} 


\section{1 ÚVOD}

Pri autonómnych vozidlách je ciel'om Európskej únie, aby sa Európa stala svetovým lídrom pri zavádzaní prepojenej a automatizovanej mobility, čo by pre ňu znamenalo významnú zmenu, pokial' ide o znižovanie počtu smrtel'ných nehôd na cestách, znižovanie škodlivých emisií z cestnej dopravy a obmedzenie dopravného pret’aženia. Je možné očakávat', že zavedenie mobility bez vodiča - po úplnom začlenení do celého dopravného systému a v kombinácii s vhodnými podpornými opatreniami a synergiami medzi mobilitou bez vodiča a opatreniami na elimináciu emisií uhlíka - sa významne prispeje k dosiahnutiu týchto klúčových spoločenských ciel’ov. V konečnom dôsledku by prevádzka autonómnych vozidiel mala viest' $\mathrm{k}$ dosiahnutiu tzv. vízie nulovej nehodovosti, t. j. k situácii, ked' na európskych cestách nebude do roku 2050 dochádzat' k žiadnym smrtel'ným nehodám. ${ }^{2}$ Táto ambícia si bude vyžadovat', aby orgány Európskej únie, súkromné subjekty, členské štáty, regionálne a miestne orgány spolupracovali na spoločnej vízii prepojenej a automatizovanej mobility.

\section{2 ÚROVNE AUTOMATIZÁCIE RIADENIA AUTONÓMNYCH VOZIDIEL}

Plne automatizované vozidlá ešte nie sú pripravené na prevádzku v cestnej premávke bez l'udského dohl'adu. Ešte stále existuje vel'a technických problémov, ktoré treba vyriešit', aby sa zabezpečilo, že vozidlo dokáže plne rozpoznat' svoje okolie, porozumiet' mu a podniknút' správne kroky, aké robí živý vodič. Rôzne úrovne automatizácie sú opísané na nasledujúcom obrázku.

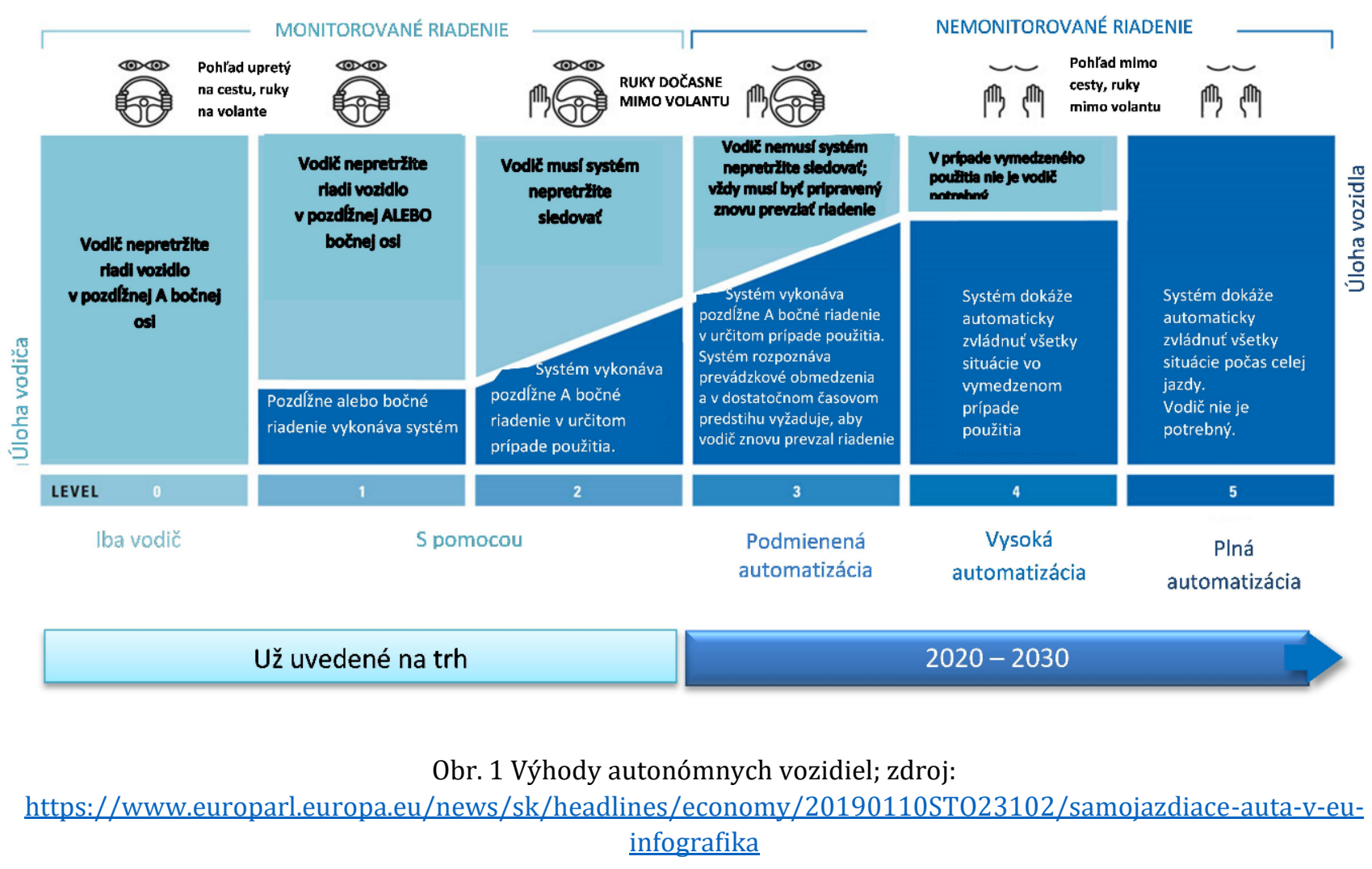

\footnotetext{
2 Biela kniha: Plán jednotného európskeho dopravného priestoru - Vytvorenie konkurencieschopného dopravnému systému efektívne využívajúceho zdroje, KOM(2011) 144.
} 
Šest'stupňová klasifikácia (od úrovne 0 - žiadna automatizácia až do úrovne 5 - úplná automatizácia) zohl'adňuje schopnost' vozidla ovládat' vozidlo, porozumiet' okoliu a umožnit' vodičovi venovat' pozornost' iným činnostiam počas jazdy. ${ }^{3}$ Jednotlivé úrovne automatizácie riadenia vozidla sú nasledovné:

- Úroveň 0 - žiadna automatizácia: vodič je zodpovedný za vykonávanie všetkých dynamických jazdných úloh (pozdížnych a priečnych) počas jazdy a za monitorovanie životného prostredia. Úroveň 0 je definovaná ako „žiadna automatizácia“; napriek tomu do tejto triedy patria dve sady systémov zasahujúcich bez vstupu vodiča, a to

1. núdzové systémy, kde patrí protiblokovací brzdový systém - ABS (Anti-lock Braking System alebo Anti Blocking System), systém trakčnej kontroly - TCR (Traction Control System), elektronická kontrola stability - ESP alebo ESC (Electronic Stability Program alebo Electronic Stability Control), brzdový asistent - BAS (Brake Assistant System), asistent núdzového brzdenia - EBA(Emergency Brake Assist),

2. varovné systémy, kde patrí akustická kontrola parkovania - PDC (Park Distance Control), asistent zmeny jazdných pruhov - LCA (Lane Change Assist), systém varovania pred vybočením z jazdných pruhov - LDWS (Lane Departure Warning), protikolízne varovanie - FCW (Front Collision Warning).

Aj ked' tieto systémy zabezpečujú priečne alebo pozdĺžne riadenie v špecifických situáciách, tieto funkcie sa stále považujú za neautomatizované, pretože zasahujú na krátke a nie trvalé obdobie.

- Úroveň 1 - asistencia pre vodiča: automatizované systémy úrovne 1 vykonávajú iba čiastkové úlohy dynamickej jazdy (pozdížna alebo bočná kontrola). Vodič vozidla je zodpovedný za vedenie vozidla, sledovanie cestnej premávky a reagovanie na ňu, dohl'ad nad automatizovanou úlohou dynamickej jazdy, vykonávanie dynamických úloh riadenia, ktoré nie sú automatizované a aktiváciu/deaktiváciu systémov pomoci. Medzi takéto systémy patrí parkovací asistent s automatizovaným riadením - PA (Park Assist), asistent sledovania jazdných pruhov - LKA (Lane Keeping Assist), adaptívny tempomat - ACC (Adaptive Cruise Control).

- Úroveň 2 - čiastočná automatizácia: automatizované systémy úrovne 2 vykonávajú časti pozdĺžneho (zrýchl'ovacieho/brzdiaceho) a bočného (riadiaceho) riadenia. Vodič vozidla je zodpovedný za monitorovanie a reakciu na podmienky cestnej premávky, za dohl'ad nad automatizovanou úlohou dynamickej jazdy aktiváciu a deaktiváciu automatizovaných systémov. Pri tejto úrovni automatizácie vodič vozidla môže za určitých okolností prestat' fyzicky ovládat' vozidlo, napríklad môže mat' ruky mimo volantu. Musí však neustále monitorovat' cestnú premávku a musí byt' schopný okamžite prevziat' úplnú kontrolu nad vozidlom, ak je to potrebné. Medzi takéto systémy patrí parkovací asistent - PA2 (Park Assist Level 2), asistent pre jazdu v dopravnej zápche (Traffic Jam Assist).

- Úroveň 3 - automatizácia za určitých podmienok (podmienená automatizácia): automatizované systémy úrovne 3 sú schopné za určitých podmienok, napríklad dopravné zápchy na dial'nici, vykonávat' jednu alebo viacero dynamických jazdných úloh a bezpečnostných funkcií vrátane sledovania cestnej premávky. Od vodiča vozidla sa nevyžaduje, aby nepretržite monitoroval automatizované úlohy dynamickej jazdy, ked' je systém aktívny, ale musí byt' schopný prevziat' kontrolu s primeraným časom reakcie, ak je to potrebné. Systém musí varovat' vodiča vozidla vopred, ak si podmienky vyžadujú prechod na riadenie vodičom. Medzi takéto systémy patrí asistenčný systém vodiča v dopravných zápchach a na dial'niciach (Traffic Jam and Highway Chauffeurs).

- Úroveň 4 - vysoká automatizácia: automatizované systémy úrovne 4 vykonávajú všetky aspekty dynamických jazdných úloh za špecifických podmienok podobným spôsobom ako systémy úrovne 3. Systémy pod úrovňou 4 však nevyžadujú, aby vodič riešil núdzové situácie. Pokial' nie sú splnené konštrukčné podmienky pre riešenie krízových situácií, systém sám iniciuje deaktiváciu, pričom úplne deaktivovat' sa môže až ked' vodič vozidla prevezme kontrolu nad vozidlom alebo sa dosiahne stav minimálneho rizika. Vodič vozidla môže vykonávat' rôzne sekundárne akcie, zatial' čo je automatizovaný systém aktívny.

\footnotetext{
${ }^{3}$ Study of the European Parliament's Committee on Transport and Tourism: Research for TRAN Committee - Selfpiloted cars: The future of road transport?, European Union, 2016, p. 110, ISBN 978-92-823-9056-6.
} 
- Úroveň 5 - plná automatizácia: automatizované systémy úrovne 5 sú schopné vykonávat’ všetky aspekty dynamických jazdných úloh za všetkých podmienok cestnej premávky. Až táto úroveň sa dá správne pomenovat' ako „samojazdiace vozidlo“ - vozidlo určené na automatizované riadenie bez kontroly človeka (vodiča vozidla).

Dnes už na európskom trhu existujú vozidlá s asistenciou riadenia, ide o prvú a druhú úroveň stupňa automatizácie. Tieto vozidlá je možné bez problémov schválit’ na prevádzku v cestnej premávke podl’a súčasných právnych predpisov.

Autonómne vozidlá tretej a štvrtej úrovne stupňa automatizácie sa práve testujú, pričom ich uvedenie na trh sa očakáva v tejto dekáde (roky 2020 až 2030). Schválenie na prevádzku v cestnej premávke týchto vozidiel je možné na základe výnimky udelenej na základe vnútroštátneho ad hoc posúdenia bezpečnosti. Na základe udelených výnimiek sa postupne budú prispôsobovat' regulačné akty pre schval'ovanie vozidiel na prevádzku v cestnej premávke.

Plne autonómne vozidlá, piata úroveň stupňa automatizácie, by sa mohli predávat' okolo roku $2030{ }^{4}$ Pre schválenie týchto vozidiel na prevádzku v cestnej premávke bude potrebná úprava predpisov pre schval'ovanie vozidiel na prevádzku v cestnej premávke.

\section{VÝNIMKA NA ZÁKLADE VNÚTROŠTÁTNEHO AD HOC POSÚDENIA BEZPEČNOSTI}

Výnimky na základe vnútroštátneho ad hoc posúdenia bezpečnosti upravuje článok 39 (Výnimky pre nové technológie alebo nové koncepcie) nariadenia Európskeho parlamentu a Rady (EÚ) 2018/858, podl'a ktorého výrobca môže požiadat' o typové schválenie EÚ pre typ vozidla, ktorý zahŕňa nové technológie alebo nové koncepcie, ktoré sú nezlučitel'né s jedným alebo viacerými regulačnými aktmi.

Schval’ovací orgán udelí typové schválenie EÚ vozidla, ak sú splnené všetky tieto podmienky:

a) v žiadosti o typové schválenie EÚ vozidla sa uvádzajú dôvody, prečo sú vozidlá v dôsledku nových technológií alebo nových koncepcií nezlučitel’né s jedným alebo viacerými regulačnými aktmi,

b) v žiadosti o typové schválenie EÚ vozidla sa opisuje vplyv novej technológie alebo novej koncepcie na bezpečnost' a životné prostredie a opatrenia prijaté na zabezpečenie minimálne rovnakej úrovne bezpečnosti a ochrany životného prostredia, akú zabezpečujú požiadavky, v súvislosti s ktorými sa žiada o výnimku z uplatňovania,

c) sú predložené opisy a výsledky skúšok, ktoré preukazujú, že predchádzajúca podmienka uvedená v písmene b) je splnená.

Udelenie typových schválení EÚ, ktorými sa novým technológiám alebo novým koncepciám udel’uje výnimka, podlieha povoleniu zo strany Európskej komisie. Schval'ovací orgán môže do prijatia povolenia zo strany Európskej komisie udelit’ predbežné typové schválenie EÚ pre typ vozidla, na ktorý sa vzt’ahuje požadovaná výnimka, ktoré bude platné len na území členského štátu daného schval'ovacieho orgánu. Schval'ovacie orgány ostatných členských štátov môžu akceptovat' predbežné typové schválenie EÚ vozidla. Európska komisia v povolení spresní, či povolenie podlieha nejakým obmedzeniam, najmä pokial' ide o počet vozidiel. Pokial' Európska komisia povolila udelit' typové schválenie EÚ vozidla, tak toto typové schválenie EÚ vozidla je platné minimálne 36 mesiacov a ide o dočasné typové schválenie EÚ vozidla.

Ak Európska komisia zamietne vydanie povolenia, schval'ovací orgán bezodkladne informuje držitel'a predbežného typového schválenia EÚ vozidla o tom, že predbežné typové schválenie EÚ vozidla sa zruší do šiestich mesiacov. Vozidlá vyrobené v zhode $\mathrm{s}$ predbežným typovým schválením EÚ vozidla pred

\footnotetext{
${ }^{4}$ https://www.europarl.europa.eu/news/sk/headlines/economy/20190110ST023102/samojazdiace-auta-v-euinfografika.
} 
skončením jeho platnosti sa môžu uviest' na trh, prihlásit' do evidencie alebo uviest' do prevádzky v každom členskom štáte, ktorý uznal predbežné typové schválenie EÚ vozidla.

Ak Európska komisia povolila udelenie typového schválenia EÚ vozidla, bezodkladne podnikne kroky potrebné na prispôsobenie dotknutých regulačných aktov (predpisov EÚ alebo predpisov EHK OSN) najnovšiemu technologickému vývoju.

\section{POSTUP UDELENIA TYPOVÉHO SCHVÁLENIA EÚ VOZIDLA NA ZÁKLADE VÝNIMKY PRE NOVÉ TECHNOLÓGIE ALEBO NOVÉ KONCEPCIE}

Výrobca vozidla podáva žiadost' pre typové schválenie EÚ vozidla typového schval'ovaciemu orgánu jedného členského štátu. Členský štát môže udelit' predbežné typové schválenie vozidla, platné iba na jeho území, pre typ vozidla, na ktoré sa nevzt'ahuje požadovaná výnimka, za predpokladu, že o tom bezodkladne informuje Európsku komisiu a ostatné členské štáty prostredníctvom oznámenia, ktoré obsahuje nasledujúce prvky:

a) dôvody, prečo príslušné technológie alebo koncepcie spôsobujú, že celý typ vozidla je nezlučitel'ný s technickými požiadavkami; je potrebné uviest', ktoré systémy, komponenty a samostatné technické jednotky sú v súlade s regulačnými aktmi (predpisy EÚ alebo predpisy EHK OSN), a ktoré nie. Mali by sa zvážit’ aj interakcie medzi rôznymi systémami vozidiel na účely automatizovanej funkcie jazdy,

b) opis príslušných bezpečnostných a environmentálnych aspektov a prijatých opatrení. Európska komisia a členské štáty sa môžu dohodnút', že ako základ použijú návrh zmeny a doplnenia príslušných regulačných aktov (predpisov EÚ alebo predpisov EHK OSN),

c) opis skúšok vrátane ich výsledkov, ktoré preukazujú, že pri porovnaní s technickými požiadavkami, od ktorých sa žiada výnimka, je zabezpečená aspoň rovnocenná úroveň bezpečnosti a ochrany životného prostredia.

Európska komisia prostredníctvom vykonávacieho aktu na základe hlasovanie v Technickom výbore pre motorové vozidlá (TCMV5) rozhodne, či povolí alebo nepovolí členskému štátu udelit' dočasné typové schválenie EÚ pre tento typ vozidla (prevedením predbežného typového schválenia). Vykonávacie rozhodnutie Európskej komisie sa zverejní vo vestníku EÚ.

$\mathrm{Na}$ základe posúdenia rizika a možných nadchádzajúcich harmonizovaných technických požiadaviek možno platnost’ dočasného typového schválenia EÚ obmedzit’ v čase (minimálne na 36 mesiacov) alebo v počte kusov vyrobených vozidiel. Ak sa nevykonajú potrebné kroky na prispôsobenie regulačných aktov, platnost' výnimky sa môže predížit' d’alším vykonávacím rozhodnutím Európskej komisie.

Až do rozhodnutia Európskej komisie môžu iné členské štáty rozhodnút' o prijatí predbežného typového schválenia na svojom území.

Rozsah už udelenej výnimky sa môže rozšírit' iným vykonávacím rozhodnutím Európskej komisie na základe zjednodušenej dokumentácie poskytnutej typovým schval’ovacím orgánom vysvetlujúcim rozdiel medzi novým typom vozidla a predchádzajúcim typom vozidla, na ktorý sa už vzt’ahuje výnimka.

\section{BEZPEČNOSTNÉ POŽIADAVKY}

Bezpečnostné požiadavky pri povolení výnimky pre nové technológie alebo nové koncepcie podl’a odporúčaní typových schval'ovacích orgánov 6 je možné rozdelit' do nasledovných 8 okruhov:

1. Systémová výkonnost'v automatizovanom móde jazdenia:

\footnotetext{
5 Technical Committee on Motor Vehicles.

${ }^{6}$ https://ec.europa.eu/docsroom/documents/34802/attachments/1/translations/en/renditions/native.
} 
a) Ak je vozidlo v automatizovanom móde jazdenia („prevádzková doména“), automatizované vozidlo nahradí vodiča vo všetkých úlohách vodiča v situáciách, ktoré možno primerane očakávat' v prevádzkovej doméne.

b) Ak je vozidlo $\mathrm{v}$ automatizovanom móde jazdenia, nesmie spôsobit' žiadne dopravné nehody, ktoré sú racionálne predvídatel'né a dá sa im zabránit'.

c) Ak je vozidlo $\mathrm{v}$ automatizovanom móde jazdenia, musí mat' predvídatel'né a starostlivé správanie a musí umožnit' primeranú interakciu s ostatnými účastníkmi cestnej premávky (napr. podl’a pokynov autorít alebo v prípade potreby komunikovat' s ostatnými účastníkmi cestnej premávky).

d) Ak je vozidlo v automatizovanom móde jazdenia („prevádzková doména“), automatizovaný systém musí viest' vozidlo v súlade s pravidlami cestnej premávky.

e) Výrobca vyhlási typovému schval'ovaciemu orgánu rozsah automatizovaného módu jazdenia („prevádzkovú doménu“), kde a kedy je automatizovaný systém jazdenia určený na prevádzku v cestnej premávke. Toto zahŕňa minimálne:

- cestné podmienky (dial'nice/rýchlostné cesty, všeobecné cesty, počet jazdných pruhov, existencia značiek jazdných pruhov, cesty určené pre vozidlá s automatizovaným riadením atd'.);

- geografická oblast' (mestské a horské oblasti);

- environmentálne podmienky (počasie, nočné limity atd'.);

- rozsah rýchlosti;

- ostatné podmienky, ktoré musia byt' splnené pre bezpečnú prevádzku vozidla v cestnej premávke v režime jazdy.

f) Automatizovaný systém jazdy musí rozpoznat', či sa situácia nachádza v rámci nastavenej prevádzkovej domény, a či funguje v tejto doméne.

g) Systém musí byt' navrhnutý bezpečne, musí byt' schopný zvládnut' akúkol'vek situáciu v rámci prevádzkovej domény (schopnosti vnímania okolia, schopnost' prijímat' správne rozhodnutia a vykonávat' správne dynamické jazdné úlohy a umožňovat' interakciu s ostatnými účastníkmi cestnej premávky) bez neustáleho dohl'adu vodiča. Konštrukcia vozidla musí zabezpečit', aby vozidlo nespôsobilo dopravnú nehodu v rámci optického systému. Vozidlo musí byt' navrhnuté tak, aby minimalizovalo potenciálne účinky chýb používatel’ov vozidiel vo vnútri vozidla alebo zvonku vozidla a ostatných účastníkov cestnej premávky.

h) Vozidlo musí byt' schopné najmä udržiavat' bezpečnú vzdialenost' za iným vozidlom, ktoré sa nachádza vpredu, musí byt' opatrné v uzavretých priestoroch, musí nechat' čas a priestor pre ostatné vozidlá v bočných manévroch, musí byt' opatrné s vozidlami s právom prednostnej jazdy a ak sa dá dopravnej nehode bezpečne vyhnút' bez toho, aby spôsobila inú dopravnú nehodu, musí sa tomu zabránit'.

i) Prevádzková doména musí byt' nastavená tak, aby vodičovi umožnila bezpečne prevziat' automatizovaný systém (t.j. len v situáciách s nízkym rizikom) a v súlade s príslušnými pravidlami cestnej premávky.

j) Systém musí zistit', kedy je zložité pokračovat' v automatizovanom móde jazdenia, napríklad pri dosiahnutí hraníc prevádzkovej domény alebo v prípade poruchy.

2. Interakcia medzi vodičom, operátorom a cestujúcim:

a) Aktivácia automatizovaného módu jazdenia je možná iba vtedy, ked' sú splnené všetky podmienky prevádzkovej domény. L'udským osobám (vodičovi alebo v prípade, že nie je vodičom, cestujúcim alebo kontrolnému stredisku prevádzky), musia byt' poskytnuté prostriedky na jednoduché deaktivovanie alebo ukončenie automatizovaného módu jazdenia. Systém však môže dočasne oddialit' deaktiváciu, ked' okamžitá deaktivácia nie je možná alebo môže ohrozit' bezpečnost'.

b) Vozidlo vždy jednoznačne informuje vodiča (alebo osobu zodpovednú za prevádzku) alebo cestujúcich o prevádzkovom stave systému (prevádzka, porucha atd'.).

c) Vodič si musí uvedomovat' limity a použitel'nost' automatizovaného módu jazdenia, ako aj úlohy, ktoré môžu byt' vodičovi, systémom umožnené.

d) Ak je systém navrhnutý tak, aby za určitých okolností vyžadoval prevzatie vedenia vozidla vodičom, systém monitoruje, či je vodič pripravený prevziat' riadenie $\mathrm{z}$ automatizovaného módu jazdenia. Toto musí byt' zabezpečené prostredníctvom vhodnej požiadavky (monitorovací systém vodiča atd'.) a varovania, že vodič je k dispozícii reagovat' na túto požiadavku o prevzatie riadenia vozidla 
a zabráni tak akémukol’vek nepredvídatel’nému a možnému zneužitiu vodičom v prevádzkovej doméne.

e) Vo vozidlách konštruovaných na prevádzku bez vodiča (napr. kyvadlová doprava bez vodiča) musí byt’ zabezpečená komunikačná funkcia na zasielanie núdzového oznámenia operačnému stredisku riadenia. Vo vozidle musí byt' umiestnená kamera a hlasové komunikačné zariadenie, aby stredisko pre riadenie prevádzky mohlo monitorovat’ situáciu vo vnútri vozidla.

3. Prechod medzi jazdnými úlohami:

a) Systém môže požiadat' vodiča o prevzatie riadenia s dostatočnou lehotou, najmä ked' systém zistí, že je t'ažké pokračovat' v automatizovanom móde jazdenia, ako napríklad v prípade, ked' sa situácia stane mimo prevádzkovej domény alebo ked' sa vyskytne problém s vozidlom.

b) Systém musí zostat' v automatizovanom móde jazdenia, pokial' ho vodič neprevzal a/alebo inak prejde na minimálny rizikový manéver.

c) Systém musí byt' navrhnutý tak, aby vodičovi umožnil jasne rozpoznat' žiadost' o prevzatie $\mathrm{z}$ automatizovaného módu jazdenia.

d) Systém musí byt' schopný určit', či vodič prevzal riadenie vozidla.

4. Minimálny rizikový manéver:

a) Ak systém zistí, že je t’ažké pokračovat' v automatizovanom móde jazdenia, musí byt' schopný prejst' do stavu minimálneho rizika (so žiadost’ou o prevzatie alebo bez neho) prostredníctvom minimálne rizikového manévru.

b) Ostatní účastníci cestnej premávky musia byt' informovaní o tom, že vozidlo vykonáva minimálny rizikový manéver v súlade s platnými pravidlami cestnej premávky (napr. výstražná funkcia smerových svietidiel, brzdové svietidlá).

c) Minimálny rizikový manéver musí byt' v súlade s pravidlami cestnej premávky. Nastavenie minimálne rizikového manévru pre automatizované vozidlá môžu zahŕňat' opatrenia na zastavenie alebo zmenu jazdného pruhu spolu s varovaním okolia a autonómne zastavenie vozidla bezpečným spôsobom na okraji cesty. Vodič môže byt' požiadaný o prevzatie na konci minimálneho rizikového manévru (napr. zaparkovanie na kraji cesty v prípade úrovne 3 systému udržiavania jazdných pruhov).

5. Inštalácia zariadenia na zaznamenávanie údajov o udalostiach:

a) Autonómne vozidlá musia byt' vybavené vozidlovým zariadením, ktoré zaznamenáva prevádzkový stav automatizovaného systému jazdy a stav vodiča, aby sa určilo, kto počas dopravnej nehody riadil vozidlo.

b) Takto zozbierané údaje umožňujú určit’ zodpovednost' v prípade dopravnej nehody a umožňujú posúdit', či vodič alebo vozidlo správne reagovali na danú situáciu. Zahŕňa prevádzkový stav automatizovaného systému riadenia, stav vodiča, informácie o okolitom prostredí a kontrolné informácie o vozidle.

c) Zariadenie na zaznamenávanie údajov musí byt' schopné zvládnut’ nárazy vozidla (podobné ako napr. odolnost' proti akcelerácii a odolnost' proti ohňu).

d) Zariadenie na zaznamenávanie údajov musí byt' schopné uchovávat' údaje bezpečným spôsobom, musí byt' v súlade s právnymi predpismi EÚ o ochrane osobných údajov, musí byt' chránené proti manipulácii a musí umožnit' prístup príslušných vnútroštátnych orgánov.

e) Na základe získaných skúseností je potrebné ustanovit' konkrétnejšie technické požiadavky na zariadenia na zaznamenávanie údajov (čas záznamu, čas uchovávania, na aké účely sa zaznamenané údaje používajú, štandardizovaný prístup k zaznamenaným údajom, spôsob zaobchádzania s osobnými údajmi a podobne).

6. Kybernetická bezpečnost'

a) Vozidlo musí byt' konštruované tak, aby bolo chránené pred hackovaním, pomocou najmodernejších techník v súlade s právnymi predpismi EÚ o ochrane osobných údajov. Zahŕňa to hodnotenie rizika zo strany výrobcu, navrhované opatrenia a primerané procesy s ciel'om zabránit' kybernetickým útokom, zmiernit' ich a reagovat' na ne.

b) Výrobcovia vozidiel prijmú také opatrenia, ako sú opatrenia súvisiace s aktualizáciou softvéru nainštalované vautonómnych vozidlách, ktoré sú potrebné na zabezpečenie kybernetickej bezpečnosti počas životnosti vozidla. 


\section{Posúdenie bezpečnosti a skúšky}

a) Automatizované vozidlá, ich systémy, komponenty a technické jednotky musia v čo najväčšej miere spíňat' súčasné technické požiadavky regulačných aktov uvedených v prílohe II nariadenia (EÚ) 2018/858, pokial' nie sú nezlučitel'né s účelom autonómnych vozidiel.

b) Typový schval'ovací orgán posúdi, či výrobca zaviedol proces navrhovania a validácie automatizovaného systému s ciel'om zabezpečit', aby vozidlo vyhovovalo stanovených usmernení typových schval'ovacích orgánov, nespôsobilo dopravnú nehodu, ako poskytuje žiadosti o bezpečné prevzatie z automatizovaného módu jazdenia a ako vykonáva minimálny rizikový manéver. Typový schval'ovací orgán musí zistit' rovnocennost' bezpečnosti na základe správy výrobcu o hodnotení bezpečnosti zdokumentovanú skúškami, validáciou a hodnotením.

c) Výrobca musí najmä preukázat', že vykonal analýzu nebezpečenstva a bezpečnostného rizika pre automatizovaný systém, jeho integráciu do celkovej konštrukcie vozidla a do širšieho ekosystému dopravy a zavedenie primeraného dizajnu, aby zvládol tieto riziká a nebezpečenstvá.

d) Systémy musia byt' navrhnuté najmä tak, aby zvládli riziká, ktoré by mohli mat' vplyv na kritickú funkčnost' $\mathrm{z}$ hl'adiska bezpečnosti $\mathrm{v}$ dôsledku kybernetických útokov a porúch (funkčná bezpečnost'), ale aj potenciálne neprimerané riadenie, nežiadúce kontrolné opatrenia, zneužitie vodiča a neprimeraná interakcia s ostatnými účastníkmi cestnej premávky (prevádzková bezpečnost').

e) Všetky konštrukčné rozhodnutia musí výrobca odskúšat', validovat' a overit' ako samostatný subsystém a ako súčast' celej architektúry vozidla.

f) Typové schval'ovacie orgány alebo technické služby konajúce v ich mene musia zistit' bezpečnú zhodu na základe vyššie uvedenej správy o hodnotení bezpečnosti výrobcu dokumentujúcej skúšanie, validáciu a metódy posudzovania uvedené vyššie. Overuje sa, či je analýza bezpečnostného rizika navrhnutá tak, aby pokrývala všetky typy porúch systému, nebezpečenstva pri jazde pre príslušný systém a hodnotila sa ich kritickost'. Posúdi sa logická schéma reakcií na riziko (napr. manévre), ktorá pokrýva celý rad identifikovaných systémových porúch a nebezpečenstva pri jazde. Typový schval'ovací orgán alebo technické služby konajúce v jeho mene zabezpečia, aby interakcie človeka s vozidlom boli riadne posúdené na základe relevantného súboru skúšok a používatel'ov. Vykonáva sa potrebný počet skúšok, aby sa overilo či vozidlo, na ktoré sa vzt'ahuje výnimka, funguje bezpečne z hl'adiska funkčnej a prevádzkovej bezpečnosti, pričom na jednej strane sa zvažujú najkritickejšie scenáre porúch a jazdy a na druhej strane opatrnost' a zrozumitel'nost' prevádzky s ostatnými účastníkmi cestnej premávky v kritických scenároch. Taktiež je potrebné zabezpečit’ transparentnú metódu merania prevádzkového výkonu systému. Dostatočný počet skúšok by mal obsahovat' falošné negatívne a falošné pozitívne testovacie scenáre. Simulačnú metódu možno použit' na základe validácie typovými schval'ovacími orgánmi/technickými službami v súlade s postupom virtuálneho testovania uvedeným v nariadení (EÚ) 2018/858.

g) Typové schval'ovacie orgány alebo technické služby konajúce v ich mene majú prístup k systému na vykonávanie posúdenia bezpečnosti vozidla.

h) Typové schval'ovacie orgány alebo technické služby konajúce v jeho mene musia mat' potrebné kvalifikácie, osvedčenia a školenie na vykonávanie vyššie uvedeného posúdenia bezpečnosti a skúšok vozidla.

\section{Poskytovanie informácií používatel’om automatizovaných vozidiel}

a) Výrobcovia vozidiel informujú používatel'ov automatizovaných vozidiel o týchto bodoch pomocou l'ahko zrozumitel'ných materiálov a prijímajú opatrenia, ktoré sú pre nich zrozumitel'né:

- prevádzkové podmienky systému, rozsah prevádzkovej domény, funkčné obmedzenia,

- prostriedky na deaktiváciu automatizovaného režimu jazdy,

- úlohy vodičov (napr. potreba vodiča prevziat' riadenie vozidla, ked' systém nemôže pokračovat' v jazde pre vozidlá úrovne 3 ),

- možné opatrenia, okrem vedenia vozidla podl’a výkonu systému a jeho prevádzkového stavu (pre vozidlá úrovne 3),

- informácie súvisiace s indikáciami HMI - Human Machine Interface (bez ohl'adu na to či automatizovaný systém jazdy funguje alebo nie),

- správanie používatel'ov v prípade naliehavosti, 
- správanie vozidla, ked' nastal problém so systémom,

- potreba vykonávat' riadnu údržbu (kontrolu) a aktualizáciu softvéru používaných automatizovaných vozidiel.

\section{REZOLÚCIA O UVÁDZANÍ VYSOKO A PLNE AUTOMATIZOVANÝCH VOZIDIEL DO CESTNEJ PREMÁVKY}

Svetové fórum pre bezpečnost' cestnej premávky (WP.1) Európskej hospodárskej komisie Organizácie Spojených národov dňa 20. septembra 2018 prijalo Rezolúciu o uvádzaní vysoko a plne automatizovaných vozidiel do cestnej premávky. ${ }^{7}$ Táto rezolúcia vznikla z dôvodu poskytnút' usmernenia na podporu bezpečného a globálneho užívania vysoko a úplne automatizovaných vozidiel v cestnej premávke. Rezolúcia obsahuje odporúčania pre vysoko automatizované systémy riadenia a odporúčania pre užívatel'ov vysoko automatizovaných systémov riadenia.

\subsection{Odporúčania pre vysoko automatizované systémy riadenia}

Vysoko automatizované systémy riadenia vo vozidlách by mali:

a) zabezpečit', aby bezpečnost' cestnej premávky bola prioritou;

b) monitorovat' a bezpečne komunikovat's okolitou cestnou premávkou a cestným prostredím;

c) bezpečne tolerovat' chyby užívatel'ov vozidiel, vo vnútri aj mimo vozidla, a chyby iných účastníkov cestnej premávky, s ciel'om minimalizovat' možné dôsledky takýchto chýb;

d) dodržiavat' pravidlá premávky, vrátane tých pravidiel:

- bezpečnej interakcii s inými účastníkmi cestnej premávky;

- rešpektovaní pokynov orgánov vykonávajúcich dohl'ad a subjektov oprávnených riadit' cestnú premávku;

- plynulosti a bezpečnosti cestnej premávky;

e) byt' v prevádzke len v rámci svojej operačnej domény;

f) byt' schopné dosiahnut' stav, ktorý zabezpečí maximálnu bezpečnost' cestnej premávky, ak jazda nemôže byt' dokončená, alebo ak by nemala byt' dokončená napríklad v prípade zlyhania automatizovaného jazdného systému alebo iného systému vozidla ;

g) reagovat' na nepredvídané situácie spôsobom, ktorý minimalizuje nebezpečenstvo pre užívatel’ov vozidla a iných účastníkov cestnej premávky;

h) komunikovat' so svojimi užívatel'mi a inými účastníkmi cestnej premávky jasne, efektívne a konzistentným spôsobom poskytovaním dostatočných informácií o ich stave a zámeroch a umožnit' vhodnú interakciu;

i) jasne a efektívne poskytovat’ príslušné upozornenia, ak vozidlo opúšt’a operačnú doménu;

j) pracovat' takým spôsobom, ktorý umožňuje overit', či vykonávajú alebo nevykonávajú dynamické ovládanie (vozidla); a

k) umožnit' ich deaktiváciu bezpečným spôsobom.

\subsection{Odporúčania pre užívatel’ov vysoko automatizovaných systémov riadenia}

Užívatelia vysoko automatizovaných systémov riadenia vo vozidlách by mali:

a) byt' vedomí a informovaní o ich správnom používaní pred začatím jazdy;

b) spíňat' podmienky pre ich bezpečné používanie a postupovat' podl'a inštrukcií na ich používanie;

c) byt' schopní komunikovat's vozidlom;

d) porozumiet' ako a kedy, je potrebné prevziat' dynamické ovládanie na dokončenie jazdy; ak je užívatel' požiadaný, alebo sa rozhodne prevziat' dynamické ovládanie, musia byt' držitel'mi príslušného vodičského preukazu a dodržiavat' pravidlá cestnej premávky;

e) vždy konat'v súlade s predpismi tak, aby neohrozovali bezpečnost' cestnej premávky bez ohl'adu na to či oni, alebo automatizované jazdné systémy vykonávajú dynamické ovládanie.

\footnotetext{
${ }^{7}$ https://www.unece.org/index.php?id=52502
} 


\section{ZÁVER}

„Autonómna jazda“ je až konečným úspechom automatizácie vozidiel a v súčasnosti si implementácia plne automatizovaných vozidiel schopných viest' vozidlo bez ohl'adu na vonkajšie podmienky stále vyžaduje značný výskum a technologický pokrok. Na trhu je už niekol'ko systémov asistencie pri riadení úrovne 0 (bez automatizácie) a úrovne 1 (asistencia vodiča) a menší počet technológií úrovne 2 (čiastočná automatizácia), ktoré sa implementujú najmä na osobné vozidlá na podporu jazdy na dial'nici, v dopravnej zápche alebo na parkovanie. Výrobcovia vozidiel zároveň investujú do výskumu a vývoja zdokonalených automatizovaných systémov do úrovne 3 (podmienená automatizácia), od ktorých sa očakáva d'alšie zlepšenie bezpečnosti vozidiel a pohodlia pri jazde. Súčasne už prebieha výskum a testovanie vyšších automatizovaných systémov (úroveň 4 - vysoká automatizácia a úroveň 5 - úplná automatizácia). Testy a skúšobné jazdy $\mathrm{v}$ tejto oblasti sa presadzujú s príspevkami rôznych organizácií vrátane výrobcov vozidiel, spoločností v oblasti informačných technológií a orgánov verejnej moci, ktorí majú záujem o implementáciu technológií autonómnej jazdy.

\section{Literatúra}

Biela kniha: Plán jednotného európskeho dopravného priestoru - Vytvorenie konkurencieschopného dopravnému systému efektívne využívajúceho zdroje, KOM(2011) 144.

European Commission: Guidelines on the exemption procedure for the EU approval of automated vehicles, Dostupné na:

https://ec.europa.eu/docsroom/documents/34802/attachments/1/translations/en/renditions/native

Global Forum for Road Traffic Safety (WP.1): Resolution on the Deployment of Highly and Fully Automated Vehicles in Road Traffic - https://www.unece.org/index.php?id=52502

Jaśkiewicz, M., Więckowski, D., 2018. Rozwiazania konstrukcyjne aktywnych zawieszen stosowanych w pojazdach, In: Autobusy, technika,eksploatacja, systemy transportowe, No 9/2018, strony: 382-386, ISSN: 1509-5878

Kalašová, A., Mikušová, M., 2017. Bezpečnost' cestnej dopravy a dopravná psychológia, Žilina: Žilinská univerzita v Žiline, ISBN 978-80-554-1329-7

Liščák, Š., Moravčík, L., Jaśkiewicz, M., 2014. Safety requirements for road vehicles, In: Zeszyty Naukowe Akademia Morska w Szczecinie - Scientific Journals Martime University of Szczecin, 2014 39(111), Szczecin, pp. 94 - 99, ISSN 1733-8670

Matoušková, I., Moravčík, L., Rak, R. a kol., 2015. eCall - Inteligentný dopravný systém (aspekty právne, technické, informačné a psychologické). Bratislava: MAGNET PRESS, SLOVAKIA s. r. o., ISBN 978-80-8916931-3, EAN 9788089169313

Moravčík, L'., Jaśkiewicz, M., 2016. Integrated Intelligent Safety Systems, In: Perner`s Contacts - Electronical technical journal of technology, engineering and logistic in transport, No 2/2016, pages 55-73, ISSN 1801$674 \mathrm{X}$

Moravčík, L., Jaśkiewicz, M., 2016. Intelligent Safety Vehicle Systems. In: AUTOBUSY - Technika, Eksploatacja, Systemy Transportowe. - ISSN 1509-5878. - č. 11 (2016) 
Moravčík, L., Jaśkiewicz, M., 2016. Safe and Intelligent Vehicle Systems. In: Automotive safety 2016: proceedings of the X International Science-Technical Conference: 22-24 February 2016, Kielce University of Technology, Kielce, PL ISBN 978-83-63792-70-1. - pages 217-226.

Moravčík, L., Jaśkiewicz, M., 2018. Ways of improoving car safety in the EU trough regulation, Perner`s Contacts - Electronical technical journal of technology, engineering and logistic in transport, No 2/2018, pages 50-56, ISSN 1801-674X

Moravčík, L., Jaśkiewicz, M., 2018. Boosting car safety in the EU. DOI: 10.1109/AUTOSAFE.2018.8373340 Nariadenie Európskeho parlamentu a Rady (EÚ) 2018/858 z 30. mája 2018 o schval'ovaní motorových vozidiel a ich prípojných vozidiel, ako aj systémov, komponentov a samostatných technických jednotiek určených pre takéto vozidlá a o dohl’ade nad trhom s nimi, ktorým sa menia nariadenia (ES) č. 715/2007 a (ES) č. 595/2009 a zrušuje smernica 2007/46/ES

Rybicka, I., Caban, J., Vrábel, J., Šarkan, B., Stopka, O., Misztal, W., 2018. Analysis of the safety systems damage on the example of a suburban transport enterprise, DOI: 10.1109/AUTOSAFE.2018.8373323

Samojazdiace autá vEÚ, Január 2020. [online], [cit. 2020-01-02]. Dostupné na: https://www.europarl.europa.eu/news/sk/headlines/economy/20190110ST023102/samojazdiace-

\section{auta-v-eu-infografika}

Správa Komisie s názvom Záchrana životov: posilnenie bezpečnosti automobilov v EÚ, COM (2016) 787. Study of the European Parliament's Committee on Transport and Tourism: Research for TRAN Committee - Self-piloted cars: The future of road transport?, European Union, 2016, p. 110, ISBN 978-92-823-9056-6, [online], [cit. 2020-01-02]. Dostupné https://www.europarl.europa.eu/RegData/etudes/STUD/2016/573434/IPOL STU(2016)573434 EN.p $\underline{\mathrm{df}}$

Šarkan, B., Vrábel, J., Skrúcaný, T., 2016. Diagnostikovanie cestných vozidiel, Žilina: Žilinská univerzita v Žiline, ISBN 978-80-554-1250-4 